\title{
THE NOVEMBER MEETING IN NASHVILLE
}

The five hundred seventy-third meeting of the American Mathematical Society was held at Vanderbilt University in Nashville, Tennessee, on Friday and Saturday, November 18-19, 1960. Eighty-eight persons registered, including fifty-five members of the Society.

By invitation of the Committee to Select House Speakers for Southeastern Sectional Meetings, Professor Gail S. Young, Jr., of Tulane University addressed the Society Friday on the topic, Topological methods for complex functions in the disk. Professor M. L. Curtiss presided at this session.

There were two sessions for contributed papers Friday afternoon and two on Saturday morning with Professors A. D. Wallace, B. O. Van Hook, W. V. Parker, and F. B. Jones presiding.

Papers numbered 573-4, 573-13, 573-18, 573-20, 573-23 and 57324, were presented by M. K. Fort, P. M. Swingle, G. C. Caldwell, H. S. Davis, R. J. Koch, and J. E. Maxfield, respectively.

G. B. HufF, Associate Secretary 